\title{
The LAbor MARKet FOr NeW Agricultural AND Resource ECONOMICS PH.D.S
}

by

Wendy A. Stock and John J. Siegfried

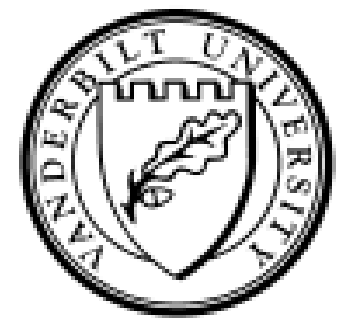

Working Paper No. 05-W04

February 2005

\section{DEPARTMENT OF ECONOMICS \\ VANDERBILT UNIVERSITY \\ NASHVILLE, TN 37235}

www.vanderbilt.edu/econ 


\title{
The Labor Market for New Agricultural and Natural Resource Economics Ph.D.s
}

\author{
Wendy A. Stock and John J. Siegfried ${ }^{*}$
}

\footnotetext{
${ }^{*}$ Stock is associate professor of economics at Montana State University. Siegfried is professor of economics at Vanderbilt University and Secretary/Treasurer of the American Economic Association. Financial support came from the Ford Foundation. Opinions, conclusions, or recommendations in this paper are those of the authors and do not necessarily reflect the views of the American Economic Association or Ford Foundation. Tyler Kruzich and Pat Fisher provided research assistance. We thank Vernon Eidman, Walter Thurman, Neilson Conklin, Bailey Norwood, seminar participants at the 2004 AAEA summer meetings, and two anonymous reviewers for valuable comments.
} 


\title{
The Labor Market for New Agricultural and Natural Resource Economics Ph.D.s
}

\begin{abstract}
This paper describes the characteristics and labor market experiences of new agricultural and natural resource (ANR) economics Ph.D.s, based on surveys of graduates in 1996-97 and 2001-02. An average of 185 new Ph.D.s in ANR economics were awarded in each of these years. Among these, an average of 27 percent were earned by women, and 36 percent were earned by U.S. citizens. The median graduate took 5.2 years to earn the Ph.D. Ninety-five percent of the graduates were employed. About half of the jobs were in academe, with the remainder divided roughly equally among government, international or research organizations, and business, industry, and consulting. The median salary of new ANR economics Ph.D.s holding full-time jobs in the U.S. was $\$ 62,500$ in 2002, up from $\$ 47,500$ five years earlier. Ninety-one percent of the respondents reported that they like their job fairly well. Those who do less research and more service are more likely to be dissatisfied with their jobs. Overall, 85 percent of the new ANR economics Ph.D.s reported that had they known at matriculation what they know after graduation, they still would have pursued a Ph.D.
\end{abstract}




\section{Introduction}

Five years ago we reported the results of a comprehensive survey of the labor market for economics Ph.D.s graduating in 1996-97 (Siegfried and Stock, 1999). We recently updated those data to include information on economics Ph.D.s graduating in 2001-02 (Siegfried and Stock, 2004). Although these papers generated some interest within the agricultural and natural resource (ANR) economics community (see, e.g., Offutt, 2002) they did not explicitly examine labor market outcomes for new Ph.D.s specializing in these fields. Indeed, only those ANR economists earning their Ph.D.s in general economics departments were included. This, of course, omitted ANR economists who earned their degrees from specialized agricultural economics departments.

This paper focuses exclusively on ANR economists, using survey data collected from the 1996-97 and 2001-02 cohorts of new Ph.D.s in ANR economics who earned their degrees in either general economics departments or in specialized agricultural economics departments. We provide information on time-to-degree, employment, salaries, and job satisfaction among these new Ph.D.s. This information should be of interest to current and prospective ANR economics Ph.D. students, of use to advisors of undergraduates considering graduate study in agricultural and natural resource economics, and of assistance to faculty concerned with the employment prospects of applicants they admit to their doctoral programs.

\section{The Survey}

There are several alternative measures of the ANR economics population of new Ph.D.s, but each is incomplete. For example, each calendar year the American Journal of Agricultural Economics (AJAE) lists Ph.D. recipients. As we describe in more detail below, this list tends to undercount those earning their degrees from general economics departments (e.g., University of Colorado, 
Duke, MIT). A list of Ph.D. recipients also appears each year in the Journal of Economic Literature (JEL). The JEL list tends to undercount those who earn their degrees from specialized agricultural economics departments (e.g., Oklahoma State Agricultural Economics, Louisiana State Agricultural Economics and Agribusiness, Rhode Island Environmental and Natural Resource Economics).

Despite this shortcoming, we identified our survey population from the listings of Ph.D. dissertations in the December 1997 and December 2002 issues of the JEL, sending two surveys to this population. The first, conducted in 1998, included individuals who earned a Ph.D. in economics between July 1, 1996 and June 30, 1997. The second, conducted in 2003, included individuals who earned a Ph.D. in economics between July 1, 2001 and June 30, 2002. Starting from the JEL lists, respondents were selected into the ANR economics sample used in the present paper if: (1) they reported specializing in JEL category Q (Agricultural and Natural Resource Economics) on our survey form; or (2) they reported on our survey form that they earned their degree from a department of agricultural economics; or (3) their dissertation was classified in category Q in the JEL dissertation list. ${ }^{1}$ We divided the graduates into subfields of agricultural economics and natural resources economics based on their dissertation titles. For the 1996-97 cohort we have 56 useable responses from graduates; for 2001-02 we have 58.

When we were unable to elicit a survey response from a graduate, we sent a shorter survey to the graduate's dissertation advisor, asking only those questions we are confident the advisor could answer. We received 14 supplemental advisor surveys for each of the two cohorts. Consequently, we have some information on 70 of the 1996-97 ANR economics graduates and 72 of the 2001-02 graduates.

Because there is no comprehensive listing of new Ph.D.s in ANR economics, and because our sample is defined in part by responses to our surveys, it is difficult to measure our survey 
response rate. The AJAE reported 166 (148) ANR Ph.D.s earned from U.S. universities in 1996 (1997) and 146 (151) degrees earned in 2001 (2002). Taking a simple average of these numbers across the two sets of years generates the prediction that about 157 Ph.D.s were earned in ANR economics in academic-year 1996-97 and 149 were earned in 2001-02. The AJAE lists are incomplete, however, since 40 (24) of the 90 (74) graduates listed under category Q of the 1996-97 (2001-02) JEL list are excluded from the 1996 and 1997 (2001 and 2002) AJAE lists. Thus, it appears that roughly 40 percent of the new ANR Ph.D.s included in the JEL list each year are not reported in the $A J A E$ list. Alternatively, about half of those on the $A J A E$ list are not reported in the JEL list. This mismatch appears primarily because the JEL tends to undercount those who earn their degrees from specialized agricultural economics departments (e.g., Oklahoma State Agricultural Economics, Louisiana State Agricultural Economics and Agribusiness, Rhode Island Environmental and Natural Resource Economics) while the AJAE tends to undercount those earning their degrees from general economics departments (e.g., University of Colorado, Duke, MIT). Adding the missed graduates specializing in category $\mathrm{Q}$ from the JEL list to the AJAE predictions above implies that 197 and 173 new Ph.D.s were earned in ANR economics in 1996-97 and 200102, respectively. ${ }^{2}$ This broad count of the ANR population implies that our data cover 36 percent of the 1996-97 cohort and 42 percent of the 2001-02 cohort, somewhat smaller coverage rates than those we obtained for economics overall (Siegfried and Stock, 1999, 2004).

Our sample of 142 Ph.D.s earned their degrees from 44 different universities. ${ }^{3}$ There are 26 graduates of California-Berkeley, 12 graduates of Purdue, 11 of Illinois, eight each of Cornell and Wisconsin, and six graduates of Minnesota in the sample. No other institution has more than five graduates in the sample. All but 16 of the graduates earned their Ph.D. at a public university, and of those 126, 91 percent were awarded by 1862 Land Grant Universities. 


\section{The Sample and its Representativeness}

Summary statistics for the sample are reported in Table 1. For each cohort, we report first information on the graduates who returned our survey. Because there is likely response bias that is correlated with some of the information in the table, we also report information provided by the thesis advisors of non-respondents. Advisor response rates are less likely to be correlated with characteristics of the graduates. For example, because of the difficulty of contacting graduates who live overseas, the percent of graduates who are U.S. citizens as revealed from graduate responses is likely biased upward (compare the 64 and 57 percent U.S. citizen rates based on graduate responses in columns 1 and 4 to the 36 and 14 percent rates, respectively, based on advisor responses in columns 2 and 5). In columns 3 and 6, therefore, we inflate the advisor responses to represent the entire set of non-respondents and combine the result with the actual graduate responses in order to project statistics for the entire population. The validity of the projections depends on the accuracy of the assumption that the responses from the thesis advisors are an unbiased sample of nonrespondents.

The share of new Ph.D.s awarded to women in ANR economics is virtually the same as in economics more generally, about 27 percent averaged over the two cohorts (Siegfried and Stock, 2004). ${ }^{4}$ This implies an increase in female representation over time, since Zepeda et al. (1993) report that only 15 percent of Ph.D. degree recipients in agricultural economics were women in 1989-90. Caution is required in comparing these statistics, however, since Zepeda et al. (1993) also found that women were more likely to attend the top Ph.D. programs. Because our sample seems heavily weighted in that direction, it may overrepresent women. Moreover, because Zepeda et al. (1993) sampled a different population (AAEA members), our results are not directly comparable to theirs. 
The proportion of new ANR economics Ph.D. graduates who are not U.S. citizens is also similar to economics more generally. In the 2001-02 cohort, for example, 71 percent of new ANR economics Ph.D.s were non-U.S. citizens, compared to 63 percent for the rest of economics. Our projected 49 U.S. citizens who earned a Ph.D. in ANR economics in 2001-02 could be fitted into a single classroom at a small elite liberal arts college! As in economics more generally, where the fraction of degrees earned by non-U.S. citizens has grown by about one percentage point per year for four decades, the share of Ph.D.s awarded to international students in ANR economics has also been growing substantially, rising from about 45 percent in 1987-88 to 54 percent in 1992-93 (Marchant and Zepeda, 1995) and then surging from 56 percent in 1996-97 to 71 percent by 200102.

Based on the 2001-02 cohort, we find that 83 percent of new U.S. ANR economics Ph.D.s earned a prior degree in economics or agricultural economics; another seven percent held a prior degree in some other agriculture field. Over two-thirds held a terminal master's degree prior to entering their Ph.D. program. ${ }^{5}$ Combining both bachelor's and master's degrees, we find that 28 percent of the cohort held at least one degree in agricultural economics at the time they began their Ph.D. study.

There is an obvious response bias in favor of the graduates who found employment in academe. Again combining the two cohorts and using the projections for each year's entire population, it appears that about 38 percent of the Ph.D.s secured a job in higher education, 24 percent in business, industry, or consulting, 21 percent in government, and 16 percent in international or research organizations (e.g., World Bank, International Food Policy Research Institute (IFPRI)). The distribution of the graduates among the agricultural economics subfield and 
the natural resources economics subfield differs substantially between the two cohorts, but averages about equal shares in each subfield for the cohorts taken together.

\section{Time-to-degree}

Based on matriculation and graduation information from the graduates and their thesis advisors, we project the median time-to-degree for the class of 2001-02 as 5.2 years, up 0.3 years from 1996-97. Examining the two cohorts together, the range extended from 2.7 to an extraordinary 29.7 years, for a person who received his Ph.D. at age 59 (compared to the median age of 32 for the full sample). Only 15 of the 140 graduates for whom we have data completed their Ph.D. within four years. For the 2001-02 cohort we have time-to-degree apportioned into various categories for 53 of the graduates. The results show a median of 0.8 years to complete first-year or core preliminary examinations, an additional 2.0 years to complete all other non-dissertation requirements, and a

further 2.1 years to complete the dissertation. ${ }^{6}$ Note that these data tell us nothing about completion rates, since everyone in our sample completed the Ph.D. ${ }^{7}$

To examine variations in time-to-degree, we estimated a duration (hazard) model based on a Weibull distribution ${ }^{8}$ for the 101 graduates who answered all the necessary questions, excluding the one graduate whose time-to-degree (29.7 years) exceeded 12 years. ${ }^{9}$ The variables expected to affect time-to-degree include: particular graduate programs (i.e. binary variables for programs with at least five observations in the regression sample), whether the Ph.D. was earned in a department of agricultural or general economics, an indicator to distinguish the cohorts, type of financial support received while in the Ph.D. program, specialization in agricultural economics or natural resources economics, and socio-demographic and educational background characteristics. The regression results are reported in Table 2. We discuss below estimated coefficients for variables that are 
statistically significantly different from zero at the ten percent significance level (two-tail tests). The mean time-to-degree for the regression sample is 5.5 years.

There are at least five graduates in the regression sample from four different Ph.D. programs: California-Berkeley Agricultural and Resource Economics, Purdue Agricultural Economics, Cornell Applied Economics and Management, and Ohio State Agricultural, Environmental, and Development Economics. Binary indicators for each of these four programs are included in the regression. The empirical results indicate that Ph.D. students completed their degrees faster at each of the four programs we specifically identified, although only for Purdue and Ohio State was the time-to-degree statistically significantly less than the benchmark (all programs without an indicator in the regression). Students in Purdue's agricultural economics department finished 21 months faster at the mean than the benchmark. Ohio State students finished ten months faster.

There is no significant difference in time-to-degree between the Ph.D. students who graduated from an agricultural economics department and those whose degrees were awarded by a general economics department. Nor is there any difference in the time taken to earn degrees across the two cohorts.

We asked graduates to report the number of years they received each of two types of financial aid (e.g., teaching or research assistantship, or no-work fellowship). Included in the regression are binary variables that indicate whether each graduate ever received an assistantship (91 percent did), or ever received a no-work fellowship (50 percent did). The estimated coefficient on neither financial aid variable is statistically significant.

Students who specialized in natural resources economics completed their degrees, on average, 13.5 months faster than those specializing in agricultural economics, ceteris paribus. 
Some of this difference can be attributed to differences in the type of dissertations that the graduates completed. We have information on the type of dissertation written by the 2001-02 graduates (although not for the 1996-97 cohort, which is why type of dissertation is not included in the regression analysis). Among the 51 ANR economics graduates for whom we have complete information, 57 percent wrote a traditional single-topic treatise, while 43 percent combined a set of essays into a dissertation. ${ }^{10}$ Sixty-four percent of those specializing in natural resources and 35 percent of those specializing in agricultural economics wrote essay-style dissertations. When we estimate the duration model for these 51 graduates and include a binary indicator for type of dissertation, the results indicate that those who wrote a dissertation consisting of a set of essays had a statistically significant shorter time-to-degree by nine months ( $\mathrm{p}$-value $=0.05$ ), while the estimated difference in time-to-degree between those specializing in natural resources and those specializing in agricultural economics becomes smaller and statistically insignificant.

Finally, although gender, marital status, dependent children, and educational background (whether a graduate held a prior master's degree or a prior degree in economics) showed no relationship with time-to-degree, we did find that, ceteris paribus, older students systematically finished faster ( 0.5 months per year of age), U.S. citizens took an average of five more months than non-citizens to complete their degrees, and white graduates finished 11 months faster than nonwhites.

\section{Employment Outcomes}

We asked graduates (and their advisors) about the employment status of the 1996-97 cohort for the week of October 13, 1997, and of the 2001-02 cohort for the first week of December 2002. Only one of the 141 who reported employment status from the two cohorts was unemployed, while six 
(four women, two men) were not in the labor force. Thus the unemployment rate among the cohorts is remarkably less than one percent. Based just on our actual graduate and advisor responses (not projecting outcomes for the full populations), 80 percent of the 134 employed graduates in the cohorts held full-time permanent positions during the year after their graduation; 14 percent were in full-time temporary positions. The remaining six percent held part-time jobs. Ten percent (13) of the employed graduates were in post-doctoral appointments, in contrast to only six percent of general economics graduates (Siegfried and Stock, 2004). Only the Centers for Disease Control and IFPRI employed more than one post-doc in our sample.

Various branches of the U.S. government (e.g., the Federal Reserve and the Environmental Protection Agency) hired 10 graduates from the two cohorts, the World Bank four, and American Express three. No other employer hired more than two of our survey respondents. Thirty-six of the 134 reporting graduates found jobs outside the U.S., the largest number of which is in Canada (5). The most common employment location for the 134 new ANR Ph.D.s is Washington, D.C. (18 jobs), followed by California (12), Texas (9), and Georgia (8).

According to the graduates and their advisors, 70 percent of the employed graduates of the class of 2001-02 took a job in the U.S., down from 76 percent five years earlier. Most of this 12 percentage point change can be attributed to the growing proportion of international students. Because 91 percent of the U.S. citizens who graduated in the two cohorts accepted employment in the U.S., compared to only 52 percent of the non-citizens, the 15 percentage point decline in the proportion of graduates who are U.S. citizens from 1996-97 to 2001-02 implies a 5.9 percentage point drop in the proportion employed in the U.S. with no behavioral change in job location decisions of the graduates. 
We asked graduates in the 2001-02 cohort about the allocation of their work time among teaching, research, academic service (e.g. advising, committees), management or administration, consulting, and professional service activities. Averaging across all employment sectors, graduates spend 43 percent of their time on research, 28 percent of their time teaching, eight percent on academic service, seven percent consulting, six percent professional service, and five percent management or administration. Of course, the percentage of time spent in various activities differs across employment sectors. Those working for government report devoting 74 percent of their time to research, those working for research organizations or international organizations 45 percent, and those in academe about 44 percent. Research constitutes less than three percent of the time of those employed in business, industry, or consulting. They instead spend almost three-quarters of their time in consulting or professional service.

Not surprisingly, graduates' descriptions of their level of overall job satisfaction and their perception of how well their jobs match their expectations are related to the percentage of time they spend in different job activities. As was the case with economics graduates generally, eighty-six percent of the employed 2001-02 graduates answered yes to the question, "Had you known then what you know now, would you still have enrolled in a Ph.D. program in economics?" This group spends an average of 45 percent of their time in research and 28 percent in teaching. For those who report that they would not seek a Ph.D. if they could rewind their life, the percentage of their time spent in teaching is similar to those who would do it again (26 percent), but the percent of time spent in research is lower (34 percent) and this difference between the two groups is statistically significant at the ten percent level. When we asked the 2001-02 graduates to tell us how they feel about their job, 47 percent said they like it very much and 44 percent said they like it fairly well (for general economics, the percentages were 55 and 39, respectively). The other 9 percent dislike it at 
least somewhat. Those who said they like it very much spend an average of 50 percent of their time in research and 29 percent in teaching. Among those who disliked their jobs at least somewhat, the percentage of time spent in teaching is similar to those who like their jobs (27 percent), but the time spent in research is only 29 percent (the p-value for the difference in the means between the two groups is 0.13$)$.

Finally, it appears that more time spent on (academic and professional) service is correlated with less job satisfaction. Those who said they would enroll in a Ph.D. program again spent 12 percent of their time on service; those who would not re-enroll spent 20 percent $(p$-value $=0.10)$. The graduates who liked their jobs fairly well spent 9 percent of their time on service; those who disliked their jobs spent 16 percent $(p$-value $=0.14)$. Finally, those who reported that their job is similar to what they expected to be doing when they began their Ph.D. program spent 10 percent of their time on service; those whose expectations were dashed spent 24 percent $(\mathrm{p}$-value $=0.01)$.

\section{Salaries}

Nominal salaries for employed new Ph.D. ANR economists who held a full-time (permanent or temporary) job in the United States are reported in Table 3 for both cohorts. The median annual December 2002 salary for 2001-02 graduates was $\$ 62,500$, up from $\$ 47,500$ five years earlier. Comparable figures for the new general economics Ph.D.s are \$74,000 in December 2002 and $\$ 55,000$ five years earlier.

The median salaries for new ANR Ph.D. economists imply a compounded annual increase of 5.7 percent from 1997 through 2002. The mean annual salary for those in full-time permanent jobs is $\$ 71,900$ in December 2002, significantly higher than the $\$ 51,300$ earned in such jobs by the 1996-97 cohort. 
The median salary for all permanent full-time jobs is 28 percent higher than for all temporary full-time jobs in 2002. This premium was only 20 percent for ANR economists five years earlier. For economists in general, the permanent versus temporary job premium skyrocketed from 27 percent in 1997 to 60 percent by 2002 (Siegfried and Stock, 2004). Those new ANR Ph.D. economists with permanent jobs outside academe earned almost 50 percent more than those with permanent jobs in academe in 2002, up substantially from a comparably calculated premium of 10 percent for 1997. As we note below, however, this salary differential is not statistically significant once we control for other factors related to starting salaries in a regression.

Although based on relatively small samples reported in Table 3, we find that the proportion of eleven month academic contracts declined from 1997 to 2002 (from 44 to 35 percent). This is consistent with earlier findings by Thilmany (2000), who attributed the change to recent attempts by some universities to use nine-month contracts as an incentive to encourage faculty to pursue external funds to fill out their yearly salaries. Perhaps even more significant is the fact that the 1112 month versus 9-10 month median salary premium has declined from 26 percent in 1997 to only 10 percent in 2002. The decline in the premium reflects compounded annual starting salary increases of 6.9 percent over the five years for those in 9-10 month contracts, but only 4.0 percent for those in 11-12 month contracts. A similar pattern does not appear in economics more generally, where the 11-12 month versus 9-10 month median salary premium grew from 1997 to 2002, at the same time that the percent of new academics on 9-10 month contracts rose from 78 to 82 percent (Siegfried and Stock, 1999, 2004).

In order to isolate independent relationships between graduates' characteristics and their starting salaries, we conducted a rudimentary cross-section regression analysis. Our sample is restricted to members of the 2001-02 cohort ${ }^{11}$ who were employed in full-time permanent positions 
in the U.S. commencing no earlier than January 2001, to eliminate those graduates who had already settled into permanent employment prior to the 2001-02 job market. Academic-year salaries were not inflated to match the calendar-year salaries of others on the grounds that most assistant professors work in the summer whether they are compensated or not. We did not ask graduates about temporary summer compensation or about fringe benefits because their responses would be too difficult to quantify comparably across individuals. Finally, for the regression analysis, salaries were adjusted to reflect cost-of-living differentials at the job location relative to Washington, D.C. The adjustments used the fourth-quarter 2002 American Chamber of Commerce Researchers Association cost-of-living index (available at www.accra.org).

The regression estimates are reported in Table 4 and include controls for demographic characteristics (sex, age, marital status, dependents, race, and citizenship), educational background characteristics (whether the graduate held a prior master's degree or a prior degree in economics), the elapsed time between entering the Ph.D. program and earning the degree, an indicator for whether the graduate specialized in natural resources economics (as opposed to agricultural economics), and an indicator for whether the graduate was employed in academe. In columns 1 and 2, we limit the analysis to ANR economists, while in columns 3 and 4 we include all new 2001-02 economics Ph.D.s (including those in columns 1 and 2) in the analysis. Because of the small sample for the ANR regression, and because the regressions do not control for ex ante productivity indicators (publications, grants, etc.) caution is warranted in interpreting the results too broadly. The regression for the ANR economics sample explains 56 percent of the variation in the natural logarithm of salaries. Unless noted to the contrary, all relationships described below are significant at the 10 percent level or better (two-tailed tests). 
The results indicate a 31 percent salary penalty for females relative to males in the ANR economics sample, but not among new doctoral economists in general. ${ }^{12}$ Similarly, graduates in the ANR sample who were married earn a 26 percent premium relative to their unmarried counterparts, a difference that is smaller and not significant among the general economics sample. The regression indicates no statistically significant difference in starting salaries based on the doctorates' age, race, U.S. citizenship, or whether they had children at the time they earned their degrees. Nor is there a significant difference in salaries for those who held a degree in economics prior to beginning their doctorate study or between those who specialized in natural resources economics and those specializing in agricultural economics. There is, however, an 18 percent salary penalty for those ANR graduates in the sample who earned a master's degree prior to entering their Ph.D. program. Each year of elapsed time to earn the degree is associated with a nine percent salary penalty among the ANR sample; this penalty is a smaller four percent among economists more generally.

Finally, once we control for other factors in our regression, the salary differential between academics and non-academics becomes statistically insignificant. Similarly, although a comparison of the mean ANR salaries reported in Table 3 against those of new Ph.D. economists in general (Siegfried and Stock, 2004, Table 3) indicates that ANR Ph.D. economists suffer a 14-15 percent nominal salary deficit compared to new Ph.D. economists generally, the difference is not statistically significant in the regression analysis, as indicated by the insignificant coefficient estimate on ANR graduate in column 3. 


\section{Comparisons Among Employment Sectors}

Demographic characteristics, employment outcomes, and responses to attitudinal questions are compared across employment sectors in Table 5. A distinct pattern is immediately evidentagricultural and natural resource economists employed in business, industry, or consulting differ from those employed in other sectors, as do those in academe. Graduates in business, industry, or consulting are more likely to be male and to hold a full-time permanent job. They earn a 50 percent salary premium over their colleagues employed in other sectors, but they appear less satisfied with their jobs. They view their jobs as less closely related to their field, less commensurate with their education and training, and further from what they expected to be doing when they began their Ph.D. program. Only 71 percent of them would have pursued a Ph.D. in economics if they had known at matriculation what they know after graduation. Twenty-nine percent of them who are in permanent jobs are actively seeking a new job, compared to 21 percent for the overall sample of ANR economists. Thus, the 50 percent compensating salary differential earned by those in the business, industry and consulting sector is apparently insufficient to fully compensate for perceived differences among the jobs. The graduates employed in academe, on the other hand, earn lower salaries than those employed in other sectors, but view their jobs as more closely related to their field, more in line with their graduate education and training, and closer to what they had expected to be doing when they matriculated in their Ph.D. program.

Finally, the gap between the average response to whether their position is commensurate with their education and whether their current job is what they had expected to be doing when they began their Ph.D. program is largest for those in business, industry, and consulting. The patterns described above are consistent with academia (and perhaps government) being the expected career 
path of graduates (Hine and Cheney, 2000), so that those who obtain non-academic jobs see less match between their jobs and their education and training.

\section{Conclusion}

Approximately 185 individuals earned Ph.D.s in agricultural and natural resources economics in each of the years 1996-97 and 2001-02. We report here findings from surveys representing 36 and 42 percent, respectively, of these cohorts of graduates. Our surveys reveal that an increasing fraction (now roughly two in three) of the Ph.D.s in ANR economics are earned by non-U.S. citizens, and roughly one quarter of the Ph.D.s are earned by women.

The vast majority of new ANR economics Ph.D.s find full-time career-tracking (i.e., permanent) jobs that pay well. Among the 2001-02 cohort, these jobs paid an average starting salary of $\$ 71,900$ for those employed in the U.S. As is the case in economics more generally, there does not appear to have been an increased fraction of new graduates taking temporary jobs between 1997 and 2002, but the gap in pay between permanent and temporary jobs in the U.S. has grown substantially since 1997.

Graduates report being satisfied with their degrees and their jobs. Eighty-five percent agreed that had they known at matriculation what they know now, they still would have pursued their Ph.D., and 91 percent of the employed respondents reported that they like their job at least fairly well. On the other hand, however, 19 percent of employed graduates are in temporary jobs and an additional 20 percent of those in permanent jobs report that they were looking for other employment at the time of our surveys. This suggests that the labor market will be an ongoing, longer-term exercise for one in five new agricultural and natural resources economics Ph.D.s. 


\section{References}

Bowen, William G. and Neil L. Rudenstine. In Pursuit of the Ph.D. 1992. Princeton, NJ: Princeton University Press.

Bowen, William G., Graham Lord, and Julie Ann Sosa. "Measuring Time to the Doctorate: Reinterpretation of the Evidence." Proceedings of the National Academy of the Sciences - USA, 1991, 88, pp.713-717. Reprinted in Bowen and Rudenstine (1992).

Halvorsen, R., and R. Palmquist. "The Interpretation of Dummy Variables in Semilogarithmic Equations." American Economic Review, June 1980, 70(3), pp. 474-75.

Hine, Susan, and Laura M. Cheney. “Career Choices and Challenges Among Agricultural Economists.” Review of Agricultural Economics, Summer 2000, 22(1), pp. 34-41.

Marchant, Mary A. and Lydia Zepeda. “The Agricultural Economics Profession at the Crossroads: Survey Results of Faculty Salary, Employment, and Hiring Prospects.” American Journal of Agricultural Economics, December 1995, 77(5), pp. 1322-1328.

Offutt, Susan. “'Introducing Ourselves' First Step in Researching Ag. Economics Career Market.” The Exchange, November/December 2002, 24(6), p. 1.

Siegfried, John J. and Wendy A. Stock. "The Labor Market for New Ph.D. Economists." Journal of Economic Perspectives, Summer 1999, 13(3), pp. 115-134. . "So You Want to Earn a Ph.D. in Economics? How Long Do You Think it

Will Take?" Journal of Human Resources, Spring 2001, 36(2), pp. 364-378. . “The Labor Market for New Ph.D. Economists in 2002.” American

Economic Review, May 2004 (Papers and Proceedings), 94(2), pp. 272-285.

Thilmany, Dawn. “Gender Based Differences of Performance and Pay Among Agricultural Economics Faculty.” Review of Agricultural Economics, Summer 2000, 22(1), pp. 23-33. 
Zepeda, Lydia, Mary Marchant, and Hui-Shung Chang. “The Status of Women Agricultural Economists in Academia." Review of Agricultural Economics, September 1993, 15(3), pp. 537545. 
Table 1. Characteristics of ANR economics Ph.D. graduates by response source, with population projections

\begin{tabular}{|c|c|c|c|c|c|c|}
\hline & \multicolumn{3}{|c|}{ 1996-97 Cohort } & \multicolumn{3}{|c|}{ 2001-02 Cohort } \\
\hline & 1 & 2 & 3 & 4 & 5 & 6 \\
\hline & $\begin{array}{l}\text { Graduate } \\
\text { responses }\end{array}$ & $\begin{array}{l}\text { Advisor } \\
\text { responses }\end{array}$ & $\begin{array}{l}\text { Population } \\
\text { projections }^{b} \\
\quad \text { (based on }\end{array}$ & $\begin{array}{l}\text { Graduate } \\
\text { responses }\end{array}$ & $\begin{array}{r}\text { Advisor } \\
\text { responses }\end{array}$ & $\begin{array}{r}\text { Population } \\
\text { projections } \\
\text { (based on }\end{array}$ \\
\hline & $(n=56)^{a}$ & $(n=14)$ & $n=197)$ & $(n=58)$ & $(n=14)$ & $n=173)$ \\
\hline Percent female & 26.8 & 30.8 & 29.7 & 27.6 & 21.4 & 23.5 \\
\hline Percent U.S. citizen & 64.3 & 35.7 & 43.8 & 56.9 & 14.3 & 28.6 \\
\hline Percent white & 74.1 & - & - & 70.4 & - & - \\
\hline Median age at degree & 33.0 & - & - & 31.9 & - & - \\
\hline Percent with prior degree in economics ${ }^{c}$ & 67.9 & - & - & 82.8 & - & - \\
\hline Percent with prior master's degree ${ }^{c}$ & 64.3 & - & - & 70.7 & - & - \\
\hline Median time to degree (years) & 5.3 & 4.7 & 4.9 & 5.3 & 5.2 & 5.2 \\
\hline Percent unemployed & 0.0 & 0.0 & 0.0 & 1.7 & 0.0 & 0.6 \\
\hline Percent of employed with full-time job & 92.7 & 83.3 & 86.0 & 96.4 & 100.0 & 98.8 \\
\hline Percent of employed with permanent ${ }^{\mathrm{d}}$ job & 72.7 & 75.0 & 74.3 & 89.1 & 91.7 & 90.8 \\
\hline Percent of employed with job in U.S. & 78.2 & 66.7 & 70.0 & 74.5 & 50.0 & 58.2 \\
\hline \multicolumn{7}{|l|}{ Distribution by employment sector (percentage): ${ }^{\mathrm{e}}$} \\
\hline Percent of employed in higher education & 52.7 & 16.7 & 26.9 & 65.5 & 41.7 & 49.7 \\
\hline Percent of employed in bus/ind/consulting & 16.4 & 16.7 & 16.6 & 12.7 & 41.7 & 32.0 \\
\hline Percent of employed in government & 10.9 & 33.3 & 26.9 & 12.7 & 16.7 & 15.4 \\
\hline Percent of employed in int'l or research org. & 20.0 & 33.3 & 29.5 & 9.1 & 0.0 & 3.0 \\
\hline \multicolumn{7}{|l|}{ Distribution by field of specialization (percentage): $:^{e, f}$} \\
\hline Agricultural Economics & 44.6 & 21.4 & 28.0 & 67.2 & 64.3 & 65.3 \\
\hline Natural Resource Economics & 50.0 & 78.6 & 70.5 & 29.3 & 35.7 & 33.6 \\
\hline
\end{tabular}

Source: Authors' survey.

${ }^{a}$ Sample size varies by row, reported $n$ is maximum. All reported data are based on at least five observations.

${ }^{\mathrm{b}}$ Projections $=(.284(.335) *$ graduates' response $)+(.716(.665) *$ advisors' response $)[.284=56 / 197 ; .335=(58 / 173)]$; 197 (173) is the predicted number of 1996-97 (2001-02) U.S. Ph.D.s in ANR economics, as described in the text.

${ }^{\mathrm{c}}$ For the 1996-97 cohort, we asked for information only about the highest degree held when the respondents began their Ph.D. program. Thus, the prior degree in economics response reflects those with their highest prior degree (as opposed to any prior degree) in economics. Similarly, the percent with prior master's degree for this cohort reflects those with a master's as their highest degree held when they started their Ph.D.program.

${ }^{\mathrm{d}}$ Permanent means the job has no specific termination date. Untenured faculty are in permanent jobs if they are on a tenure track.

${ }^{\mathrm{e}}$ Distributions do not always sum to 100 because some categories are not reported.

${ }^{\mathrm{f}}$ Field is the characterization of the graduates' specialization, based on their dissertation title. 


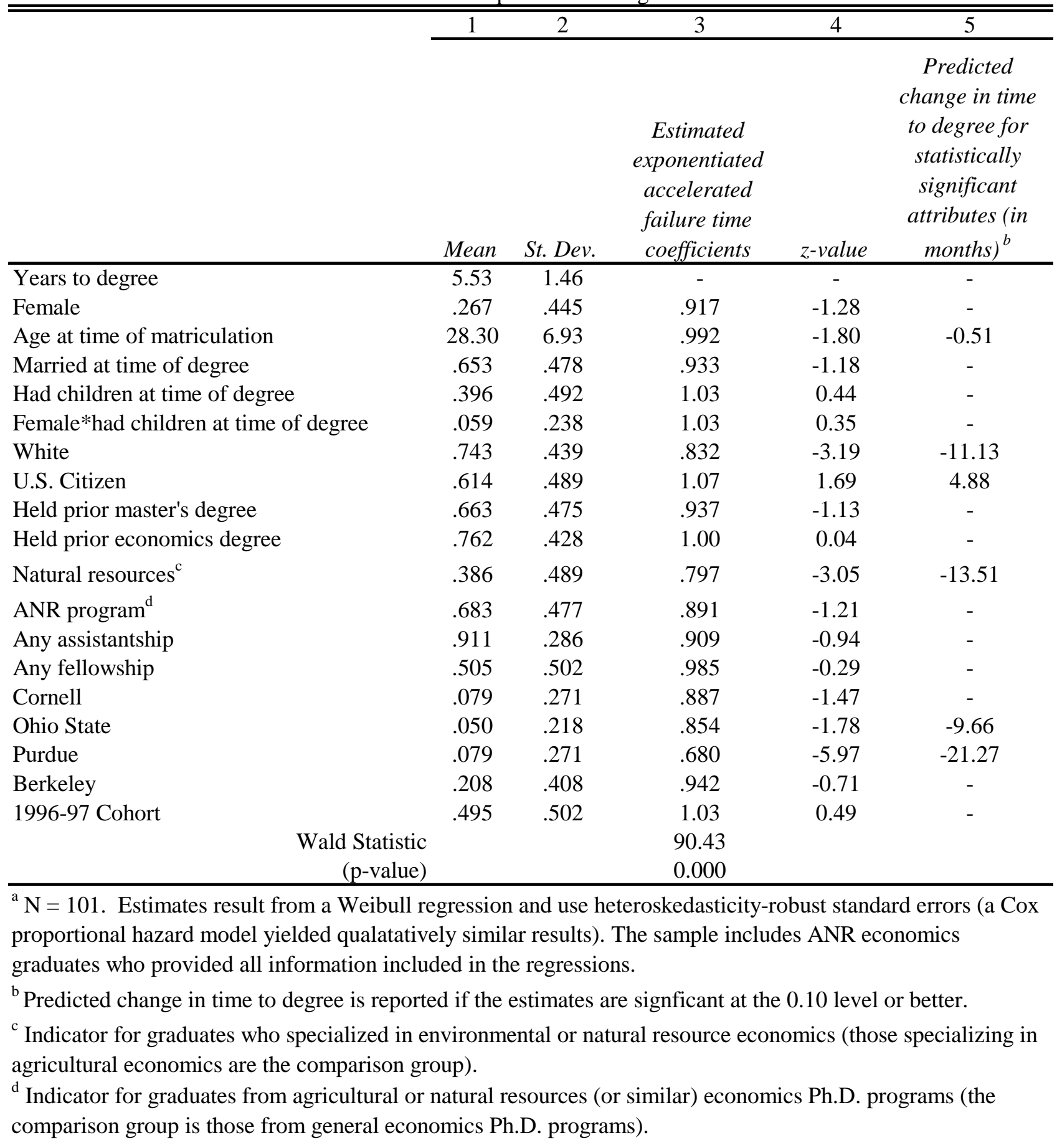


Table 3. New ANR economics Ph.D.s' annual salaries for full-time jobs in the U.S.

\begin{tabular}{|c|c|c|c|c|c|}
\hline & \multicolumn{5}{|c|}{ Panel A: 1996-97 Cohort, 1997 Nominal Salaries } \\
\hline & Median & Mean & Low & High & $N$ \\
\hline All full-time jobs in the U.S. & $\$ 47,500$ & $\$ 49,900$ & $\$ 31,800$ & $\$ 90,000$ & 40 \\
\hline Permanent positions & 49,800 & 51,300 & 35,000 & 90,000 & 32 \\
\hline Academic & 47,000 & 48,000 & 35,000 & 62,000 & 16 \\
\hline 9-10 month & 43,000 & 44,700 & 35,000 & 56,000 & 9 \\
\hline 11-12 month & 54,000 & 52,400 & 45,700 & 62,000 & 7 \\
\hline Non-academic & 55,000 & 54,500 & 35,000 & 90,000 & 16 \\
\hline \multirow[t]{3}{*}{ Temporary positions } & 41,500 & 44,300 & 31,800 & 60,000 & 8 \\
\hline & \multicolumn{5}{|c|}{ Panel B: 2001-02 Cohort, 2002 Nominal Salaries } \\
\hline & Median & Mean & Low & High & $N$ \\
\hline All full-time jobs in the U.S. & $\$ 62,500$ & $\$ 69,700$ & $\$ 30,000$ & $\$ 133,000$ & 39 \\
\hline Permanent positions & 67,000 & 71,900 & 30,000 & 133,000 & 35 \\
\hline Academic & 61,000 & 62,000 & 30,000 & 83,000 & 23 \\
\hline $9-10$ month & 60,000 & 61,400 & 44,500 & 83,000 & 15 \\
\hline 11-12 month & 65,800 & 63,300 & 30,000 & 86,000 & 8 \\
\hline Non-academic & 91,000 & 90,700 & 56,000 & 133,000 & 12 \\
\hline Temporary positions & 52,400 & 50,700 & 42,000 & 56,000 & 4 \\
\hline
\end{tabular}

Source: Authors' survey. See notes to Table 1. 


\begin{tabular}{|c|c|c|c|c|}
\hline & \multicolumn{2}{|c|}{$\begin{array}{c}\text { ANR Economics }^{\mathrm{b}} \\
(\mathrm{N}=30)\end{array}$} & \multicolumn{2}{|c|}{$\begin{array}{c}\text { All Economics } \\
(\mathrm{N}=208)\end{array}$} \\
\hline & 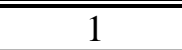 & $\overline{2}$ & $\overline{3}$ & 4 \\
\hline & $\begin{array}{l}\text { Coefficient } \\
\text { (st. error) }\end{array}$ & $\begin{array}{c}\text { Mean } \\
\text { (st. dev.) }\end{array}$ & $\begin{array}{l}\text { Coefficient } \\
\text { (st. error) }\end{array}$ & $\begin{array}{c}\text { Mean } \\
\text { (st. dev.) }\end{array}$ \\
\hline Ln(Annual Salary) & - & $\begin{array}{l}11.35 \\
(.313)\end{array}$ & - & $\begin{array}{l}11.37 \\
(.280)\end{array}$ \\
\hline Female & $\begin{array}{c}-.370^{* *} \\
(.156)\end{array}$ & $\begin{array}{c}.133 \\
(.346)\end{array}$ & $\begin{array}{l}-.022 \\
(.043)\end{array}$ & $\begin{array}{l}0.303 \\
(.461)\end{array}$ \\
\hline Age & $\begin{array}{c}.004 \\
(.005)\end{array}$ & $\begin{array}{c}33.75 \\
(10.88)\end{array}$ & $\begin{array}{l}-.001 \\
(.004)\end{array}$ & $\begin{array}{l}31.44 \\
(5.22)\end{array}$ \\
\hline Married at time of degree & $\begin{array}{l}.234 * \\
(.122)\end{array}$ & $\begin{array}{l}.633 \\
(.490)\end{array}$ & $\begin{array}{c}.040 \\
(.045)\end{array}$ & $\begin{array}{l}0.495 \\
(.501)\end{array}$ \\
\hline Had Children at time of degree & $\begin{array}{l}-.047 \\
(.141)\end{array}$ & $\begin{array}{l}.267 \\
(.450)\end{array}$ & $\begin{array}{l}-.005 \\
(.056)\end{array}$ & $\begin{array}{l}0.202 \\
(.402)\end{array}$ \\
\hline White & $\begin{array}{l}-.090 \\
(.190)\end{array}$ & $\begin{array}{l}.867 \\
(.346)\end{array}$ & $\begin{array}{c}.043 \\
(.053)\end{array}$ & $\begin{array}{l}0.779 \\
(.416)\end{array}$ \\
\hline U.S. Citizen & $\begin{array}{l}-.166 \\
(.153)\end{array}$ & $\begin{array}{c}.800 \\
(.407)\end{array}$ & $\begin{array}{l}-.047 \\
(.047)\end{array}$ & $\begin{array}{l}0.577 \\
(.495)\end{array}$ \\
\hline Held prior master's degree & $\begin{array}{l}-.204^{*} \\
(118)\end{array}$ & $\begin{array}{l}0.633 \\
(.490)\end{array}$ & $\begin{array}{l}-.016 \\
(.048)\end{array}$ & $\begin{array}{l}0.428 \\
(.496)\end{array}$ \\
\hline Held prior economics degree & $\begin{array}{l}.103 \\
(.144)\end{array}$ & $\begin{array}{l}.800 \\
(.407)\end{array}$ & $\begin{array}{l}-.004 \\
(.053)\end{array}$ & $\begin{array}{l}0.832 \\
(.375)\end{array}$ \\
\hline Time to degree (years) & $\begin{array}{c}-.089 * * \\
(.034)\end{array}$ & $\begin{array}{c}5.37 \\
(1.61)\end{array}$ & $\begin{array}{c}-.040 * * * \\
(.013)\end{array}$ & $\begin{array}{c}5.65 \\
(1.55)\end{array}$ \\
\hline Employed in academe & $\begin{array}{l}-.161 \\
(.117)\end{array}$ & $\begin{array}{l}.667 \\
(.479)\end{array}$ & $\begin{array}{l}-.018 \\
(.040)\end{array}$ & $\begin{array}{l}0.615 \\
(.488)\end{array}$ \\
\hline Natural resources ${ }^{c}$ & $\begin{array}{c}.017 \\
(.123)\end{array}$ & $\begin{array}{c}.300 \\
(.467)\end{array}$ & - & - \\
\hline ANR graduate $^{\mathrm{d}}$ & - & - & $\begin{array}{l}-.032 \\
(.059)\end{array}$ & $\begin{array}{l}0.144 \\
(.352)\end{array}$ \\
\hline $\begin{array}{l}\text { R-Squared } \\
\text { Adjusted R-Squared }\end{array}$ & $\begin{array}{l}.561 \\
.294\end{array}$ & & $\begin{array}{l}.067 \\
.014\end{array}$ & \\
\hline
\end{tabular}

${ }^{a}$ Estimates result from ordinary least squares and use heteroskedasticity-robust standard errors. $* * *=$ significant at 0.01 level; ** = significant at 0.05 level; * = significant at 0.10 level.

${ }^{\mathrm{b}}$ Columns 1 and 2 include new ANR economics graduates only. Columns 3 and 4 include all new economics graduates (including those in columns 1 and 2).

c Indicator for graduates who specialized in environmental or natural resource economics (those specializing in agricultural economics are the comparison group).

${ }^{\mathrm{d}}$ Indicator for graduates who specialized in ANR economics (the comparison group is those specializing in all other fields of economics). 
Table 5. Comparisons of ANR economists among employment sectors

\begin{tabular}{|c|c|c|c|c|c|}
\hline & $\begin{array}{l}\text { Academic } \\
(n=72)^{a}\end{array}$ & $\begin{array}{r}\text { Business, } \\
\text { Industry, } \\
\text { Consulting } \\
(n=23)\end{array}$ & $\begin{array}{r}\text { International } \\
\text { or Research } \\
\text { Organization } \\
(n=20) \\
\end{array}$ & $\begin{array}{r}\text { Government } \\
(n=19)\end{array}$ & $\begin{array}{r}\text { Total } \\
(n=134)\end{array}$ \\
\hline \multicolumn{6}{|l|}{ Background Characteristics } \\
\hline Female $^{\mathrm{b}}$ & 0.23 & $0.13^{<c}$ & 0.35 & $0.37^{>}$ & 0.25 \\
\hline U.S. citizen ${ }^{\mathrm{b}}$ & 0.58 & 0.48 & 0.50 & 0.58 & 0.55 \\
\hline Married at end of program ${ }^{\mathrm{b}}$ & 0.66 & 0.63 & 0.63 & 0.62 & 0.65 \\
\hline Had children at end of program ${ }^{\mathrm{b}}$ & 0.40 & 0.38 & 0.31 & 0.23 & 0.36 \\
\hline \multicolumn{6}{|l|}{ Employment Outcomes } \\
\hline Full-time permanent job ${ }^{\mathrm{b}}$ & 0.76 & $0.96^{>}$ & 0.70 & 0.84 & 0.80 \\
\hline Median 2001-02 cohort salary, full-time permanent job in U.S. (\$) & $61,000^{<}$ & $90,000^{>}$ & $-{ }^{d}$ & $-{ }^{d}$ & 67,000 \\
\hline Permanent job and looking for a new job ${ }^{\mathrm{b}}$ & 0.20 & 0.29 & 0.20 & 0.13 & 0.21 \\
\hline \multicolumn{6}{|l|}{ Attitudes } \\
\hline \multicolumn{6}{|l|}{ (5 = strongly agree; 1 = strongly disagree); mean is reported } \\
\hline Position is related to my field & $4.71^{>}$ & $3.43^{<}$ & 4.20 & 3.71 & 4.37 \\
\hline Position is commensurate with my education and training & $4.46^{>}$ & $4.14^{<}$ & 4.20 & 3.86 & 4.31 \\
\hline Position is what I expected to be doing when I began my Ph.D. & $3.63^{>}$ & $2.86^{<}$ & 3.40 & 3.57 & 3.50 \\
\hline 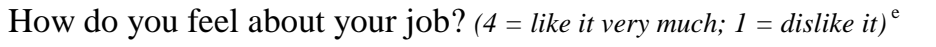 & 3.36 & 3.29 & 3.00 & 3.71 & 3.36 \\
\hline Had Known? ${ }^{e, f}$ & 0.86 & $0.71^{<}$ & 0.80 & 1.00 & 0.85 \\
\hline
\end{tabular}

Source: Authors' survey. See notes to Table 1.

${ }^{a}$ Sample size varies by row. Reported $n$ is maximum. All reported data are based on at least five observations.

${ }^{\mathrm{b}}$ Proportions.

c ">" ("<") = value is statistically significantly higher (lower) than the mean for the rest of the sample at the 0.10 level (one-tailed tests). For variables for which we report the median, we tested for differences in the mean of the variable among the groups.

${ }^{\mathrm{d}}$ Too few observations to disclose.

${ }^{\mathrm{e}}$ Reported only for 2001-02 cohort.

${ }^{\mathrm{f}}$ Proportion with yes response to: "Had you known then what you know now, would you still have enrolled in a Ph.D. program in economics?" 
Appendix Table. Comparisons among general and ANR economics Ph.D. graduates of 2001-02

\begin{tabular}{|c|c|c|c|c|c|c|}
\hline & \multicolumn{3}{|c|}{ All Economics Graduates } & \multicolumn{3}{|c|}{ ANR Economics Graduates } \\
\hline & 1 & 2 & 3 & 4 & 5 & 6 \\
\hline & Graduate & Advisor & Population & Graduate & Advisor & Population \\
\hline & responses & responses & $\begin{array}{l}\text { projections }^{b} \\
\quad \text { (based on }\end{array}$ & responses & responses & $\begin{array}{l}\text { projections }^{b} \\
\quad \text { (based on }\end{array}$ \\
\hline & $(n=398)^{a}$ & $(n=121)$ & $n=850)$ & $(n=58)$ & $(n=14)$ & $n=173)$ \\
\hline Percent female & 28.3 & 27.7 & 28.0 & 27.6 & 21.4 & 23.5 \\
\hline Percent U.S. citizen & 48.5 & 26.3 & 36.7 & 56.9 & 14.3 & 28.6 \\
\hline Percent white & 70.1 & - & - & 70.4 & - & - \\
\hline Median age at degree & 31.0 & - & - & 31.9 & - & - \\
\hline Percent with prior degree in economics & 75.9 & - & - & 82.8 & - & - \\
\hline Percent with prior master's degree & 44.5 & - & - & 70.7 & - & - \\
\hline Median time to degree (years) & 5.7 & 5.2 & 5.4 & 5.3 & 5.2 & 5.2 \\
\hline Percent unemployed & 1.5 & 2.7 & 2.1 & 1.7 & 0.0 & 0.6 \\
\hline Percent of employed with full-time job & 96.6 & 98.1 & 97.4 & 96.4 & 100.0 & 98.8 \\
\hline Percent of employed with permanent ${ }^{\mathrm{c}}$ job & 80.6 & 88.0 & 84.5 & 89.1 & 91.7 & 90.8 \\
\hline Percent of employed with job in U.S. & 82.3 & 58.7 & 69.7 & 74.5 & 50.0 & 58.2 \\
\hline \multicolumn{7}{|l|}{ Distribution by employment sector (percentage): ${ }^{\mathrm{d}}$} \\
\hline Percent of employed in higher education & 60.7 & 57.1 & 58.8 & 65.5 & 41.7 & 49.7 \\
\hline Percent of employed in bus/ind/consulting & 10.3 & 7.6 & 8.9 & 12.7 & 41.7 & 32.0 \\
\hline Percent of employed in government & 15.8 & 19.1 & 17.6 & 12.7 & 16.7 & 15.4 \\
\hline Percent of employed in int'l or research org. & 13.2 & 16.2 & 14.8 & 9.1 & 0.0 & 3.0 \\
\hline
\end{tabular}

Source: Authors' survey and Table 2 of Siegfried and Stock (2004).

${ }^{\text {a }}$ Sample size varies by row, reported $n$ is maximum. All reported data are based on at least five observations.

${ }^{\mathrm{b}}$ Projections for All Economics Graduates = .468 (graduates' response) + .532 (advisors' response) [.468 = 398/850]; 850 is estimated population of 2001-02 U.S. Ph.D.s in economics. Projections for ANR Economics Graduates $=(.335 *$ graduates' response $)+(.665 *$ advisors' response $)[.335=(58 / 173)]$; 173 is the predicted number of 2001-02 U.S. Ph.D.s in ANR economics, as described in the text.

${ }^{\mathrm{c}}$ Permanent means the job has no specific termination date. Untenured faculty are in permanent jobs if they are on a tenure track.

${ }^{\mathrm{d}}$ Distributions do not always sum to 100 because some categories are not reported. 


\section{Endnotes}

${ }^{1}$ The JEL list also includes degrees earned from Canadian universities. We eliminated these graduates from the sample.

${ }^{2}$ According to the Survey of Earned Doctorates (SED) sponsored by the National Science Foundation, 133 doctorates in agricultural economics were awarded in 1996-97, and 119 in 2001-02. The SED asks individual graduates to classify their dissertation into an academic discipline (economics) and field (i.e., economics, agricultural economics, or econometrics). Therefore, SED data should include ANR economists who graduate from regular economics as well as specialized agricultural economics departments. However, because the SED identifies the field as "agricultural economics," it is possible that many natural resources economics graduates may instead classify their field as economics more generally, leading the SED to also undercount the number of ANR economics graduates.

${ }^{3}$ The universities represented in our sample are: American University, Boston College, Boston University, Colorado School of Mines, Clark University, Cornell, Duke, George Washington University, Howard, Iowa State, Michigan State, MIT, North Carolina State, Northeastern, Ohio State, Oklahoma State, Pennsylvania State, Purdue, Stanford, SUNYBinghamton, Texas A\&M, California-Santa Barbara, Colorado, Connecticut, Delaware, Florida, Illinois, Kentucky, Maryland, Minnesota, Missouri, New Mexico, Tennessee, Texas, Utah, Washington, Wisconsin-Madison, Wyoming, California-Berkeley, California-Davis, UCLA, Utah State, Washington State, and Washington University-St. Louis.

${ }^{4}$ Comparisons to economics more generally are based on the results reported in Siegfried and Stock (2004), which include 398 graduate surveys and 121 advisor surveys for the 
2001-02 cohort and include a very small number of graduates of general economics departments who had a field in agricultural and natural resource economics (14 of the responding graduates and 4 of the responding advisors). The Appendix Table provides additional comparisons between economics and ANR economics graduates.

${ }^{5}$ Terminal master's degrees exclude those earned routinely as part of a Ph.D. program. ${ }^{6}$ Note that medians of the program components do not have to sum to the median of the total elapsed time-to-degree.

${ }^{7}$ Because we use a sample of Ph.D. graduates rather than a cohort of Ph.D. program entrants, we risk biasing the level of median time-to-degree. For example, if the size of entering cohorts is decreasing, successively smaller cohorts will be unable to fully replace faster recipients from previously larger cohorts (Bowen, Lord, and Sosa, 1990, reproduced in Bowen and Rudenstine, 1992, p. 351). Conducting an analysis of the entering cohorts of this graduating class, however, would require us to have begun our study in the 1970s.

${ }^{8}$ Estimation using a Cox proportional hazards model yielded qualitatively similar results. ${ }^{9}$ For similar analyses for 1996-97 and 2001-02 general economics doctorates, see Siegfried and Stock (2001) and (2004), respectively.

${ }^{10}$ Among the economics profession as a whole, 56 percent of the theses completed in 200102 consisted of a set of essays (Siegfried and Stock, 2004).

${ }^{11}$ We excluded 1996-97 graduates from the regression because of difficulty in comparably adjusting their salaries for geographical and time-related cost-of-living differences. 
12 The estimated percent differences in salary are computed as $\left[\mathrm{e}^{\hat{\beta}}-1\right] * 100$, following Halvorsen and Palmquist (1980). 